\title{
GÊNERO DISCURSIVO E AS NOVAS LINGUAGENS NO ENSINO DE LÍNGUA PORTUGUESA
}

\author{
DISCURSIVE GENDER AND NEW LANGUAGES IN PORTUGUESE \\ LANGUAGE TEACHING
}

\author{
Miriam Bauab Puzzo* \\ Universidade de Taubaté, Taubaté, SP, Brasil \\ Sonia Sueli Berti-Santos** \\ Universidade Cruzeiro do Sul - UNICSUL, São Paulo, SP, Brasil
}

Resumo: As novas linguagens que circulam nos mais diversos gêneros suscitam possibilidades de leitura mais produtivas em sala de aula. Assim, o objetivo deste artigo é discutir a linguagem verbo-visual de uma reportagem impressa, com o intuito de observar as relações dialógicas que perpassam pelo enunciado e seus efeitos de sentido. A teoria que sustenta a análise é fundamentada em Bakhtin e no Círculo, no que diz respeito aos gêneros discursivos, recorrendo-se também a pesquisadores dessa linha teórica que têm tratado da verbo-visualidade em diversos gêneros, como propõe Sobral (2010), Puzzo (2011), Berti-Santos (2011), Brait e Pistori (2012), Brait (2013), Dondis (2003) e Guimarães (2004). Para cumprir esta proposta, foi selecionada a reportagem História de um olhar, de Eliane Brum, da coletânea $A$ vida que ninguém vê (2006), que apresenta uma articulação significativa entre 0 texto verbal e a fotografia esteticamente trabalhada que integra 0 texto. Distancia-se, pela singularidade do estilo, das reportagens jornalísticas diárias numa linguagem marcada pela fragmentação sintática e pela expressividade, sem prejuízo da unidade enunciativa. Espera-se, com a análise desse exemplar, motivar estratégias de leitura de reportagens, observando a linguagem verbo-visual e seus efeitos de sentido em gêneros midiáticos.

Palavras-chave: gênero discursivo; leitura; reportagem; verbo-visualidade; teoria dialógica da linguagem

\begin{abstract}
The new languages that circulate in different genres increase the possibilities of reading in classroom. So the purpose of this article is to discuss the meaning effects expressed by verbal-visual language of a printed report in order to observe the dialogical relationship that underlie the utterance and its meaning effect. To accomplish this, the analysis is based on Bakhtin's Circle dialogical theory and also on some researchers' theory about verbal-visual language in various genres, as proposed by Sobral (2010), Puzzo (2011), Berti-Santos (2011), Brait and Pistori (2012), Brait (2013), Dondis (2003) e Guimarães (2004). To accomplish this proposal it was selected a news report The history of a look of Eliane Brum's from the collection The life that nobody sees (2006) which presents a significant relationship between the verbal text and the photography aesthetically crafted that integrates the utterance. Brum's expressive style distinguishes her report from the daily newspaper, marked by syntactic fragmentation without damage the entire utterance. We hope that the analysis of this example suggests strategies of reading the verbal-visual language and its effects in media genres.
\end{abstract}

Keywords: Discursive Genre; Reading; News Report; Verbal-Visuality; Dialogic Theory of Language.

* Professora doutora da Universidade de Taubaté - UNITAU, Taubaté, Brasil; puzzo@uol.com.br

** Professora doutora da Universidade Cruzeiro do Sul - UNICSUL, São Paulo, Brasil; soniasul@ vol.com.br 
Linha D'Água (Online), São Paulo, v. 28, n. 2, p. 26-43, dez 2015

\section{Introdução}

As novas linguagens e o poder de síntese em enunciados dos gêneros midiáticos exigem do professor de língua materna maior atenção no ensino de leitura. A verbo-visualidade (BRAIT, 2013) é uma das formas de expressão que explora a concisão, deixando entrever pontos de vista, posicionamentos críticos diante dos fatos do cotidiano, veiculados na mídia, nem sempre perceptíveis aos leitores pouco afeitos à análise de diferentes linguagens. A proposta deste artigo é tratar da articulação entre as linguagens verbal e visual na produção de sentido em uma reportagem jornalística. A teoria que sustenta a análise é fundamentada em Bakhtin e no Círculo, no que diz respeito ao signo ideológico, semiótico, aos gêneros discursivos: tema, forma composicional e estilo, bem como às relações dialógicas e ao tom valorativo presentes no enunciado concreto. Além disso, apesar de Bakhtin e o Círculo não tratarem da linguagem visual, os pesquisadores dessa linha teórica têm desenvolvido trabalhos que tratam da verbo-visualidade em diversos gêneros. Com esse aporte teórico, busca-se analisar uma reportagem da jornalista Eliane Brum, cuja peculiaridade é a articulação entre as linguagens verbais e visuais esteticamente trabalhadas. Conta-se também com apoio de autores como Sobral (2010), Puzzo (2011), Berti-Santos (2011), Brait e Pistori (2012), Brait (2013), Dondis (2003) e Guimarães (2004). Para desenvolver a proposta, foi selecionado um texto da coletânea de reportagens breves, que, publicadas no jornal Zero Hora, de Porto Alegre, no ano de 1999, foram reunidas no livro $A$ vida que ninguém vê (BRUM, 2006) ${ }^{1}$. As reportagens de Eliane Brum apresentam uma articulação significativa entre o texto verbal e a fotografia que o antecede.

Tendo em vista essa peculiaridade e a forma moderna de atualização da reportagem como gênero da esfera jornalística, o objetivo deste artigo é propor a análise da reportagem História de um olhar, de $A$ vida que ninguém vê (BRUM, 2006), numa perspectiva dialógica da linguagem, recuperando o diálogo que o texto estabelece com seu contexto sócio-histórico e com o leitor presumido, cujas atitudes responsivas dão acabamento ao enunciado. As reportagens que compõem essa coletânea apresentam um enfoque especial e uma proposta unificada, tanto no que tange à elaboração estética das fotos quanto na exploração expressiva da linguagem.

A análise procura resgatar o tema que organiza o enunciado, bem como os recursos expressivos utilizados. Com essa leitura, observam-se as relações dialógicas estabelecidas pelo enunciador com o contexto social, bem como o tom valorativo diante dos fatos do cotidiano.

1 O texto na íntegra e as imagens encontram-se disponíveis em: <http://portalsme.prefeitura. sp.gov.br/Projetos/ie/Documentos/historia\%20de\%20um\%20olhar\%20-\%20Eliana\%20Brun. pdf>. Acesso em 16 de out. 2015. 
De início, discutem-se os conceitos de linguagem, na perspectiva dialógica bakhtiniana, e de gênero discursivo, nuclear nessa discussão. A seguir, apresenta-se o novo enfoque dado pelas pesquisas a respeito da verbo-visualidade, contando com o apoio de pesquisadores que desenvolveram estudos interpretativos dos signos visuais, como Dondis (2003) e Guimarães (2004), contribuindo, de forma significativa, para a compreensão dessa proposta de leitura do novo gênero em questão.

Para concluir, resgatam-se aspectos da teoria dialógica articulados nessa proposta de leitura, com vistas a contribuir para a ampliação das possibilidades de trabalho com gêneros discursivos em sala de aula, especificamente, nas aulas de língua portuguesa.

\section{A verbo-visualidade e a produção de sentido}

A verbo-visualidade tem sido muito exigida, atualmente, em provas como ENEM (Exame Nacional de Ensino Médio) e ENADE (Exame Nacional de Desempenho de Estudantes), entre outros, como forma de demonstrar a capacidade de leitura do cidadão, apto a atuar em seu meio, como preconizam os Parâmetros Curriculares Nacionais (PCN). Isso implica uma atuação docente que busque instrumentalizar o educando para um desempenho satisfatório na leitura de textos verbais e verbo-visuais em diversos gêneros discursivos presentes no dia a dia do cidadão.

$\mathrm{Na}$ teoria bakhtiniana e do Círculo, encontram-se referências várias ao signo e à leitura semiótica, entendendo o signo como elemento semiótico por excelência, como parte integrante da consciência humana, conforme aponta Bakhtin/Volochinov (2006):

E a própria consciência individual está repleta de signos. A consciência, só se torna consciência quando se impregna de conteúdo ideológico (semiótico) e, consequentemente, somente no processo de interação social (p.34).

Para a compreensão do verbo-visual, é necessário entender a ideologia que subjaz ao signo e permeia as relações dialógicas entre sujeitos. Como postula Bakhtin/Volochinov (2006, p. 35-36), o ideológico só pode ser explicado a partir do material social particular de signos criados pelo homem, situado entre indivíduos organizados como seu meio de comunicação, ou seja, que constituam uma unidade social, em que os signos figurem em terreno interindividual. Nesse caso, a consciência individual é um fato socioideológico, isto é, a consciência é sociológica, constituindo-se nos signos criados por grupos organizados em relações sociais.

Se privarmos a consciência de seu conteúdo semiótico e ideológico, não sobra nada. A imagem, a palavra, o gesto significante, etc. constituem seu único 


\section{Linha D’Água (Online), São Paulo, v. 28, n. 2, p. 26-43, dez 2015}

abrigo. Fora desse material, há apenas o simples ato fisiológico, não esclarecido pela consciência, desprovido de sentido que os signos lhe conferem. (BAKHTIN; VOLOCHINOV, 2006, p. 36).

Os signos são, portanto, constituintes da consciência individual, refletida na lógica das comunicações ideológicas, que se dão no seio da interação semiótica de um grupo social organizado. A consciência individual permite a expressão da personalidade que é construída, apreendida no interior da inter-relação social (BAKHTIN; VOLOCHINOV, 2006, p. 117). Para o autor, a atividade mental do sujeito, que lhe permite estabelecer sentidos, criar enunciados, relacionar-se socialmente, constitui-se socialmente.

Quando a atividade mental se realiza sob a forma de uma enunciação, a orientação social à qual ela se submete adquire maior complexidade graças à exigência de adaptação ao contexto social imediato do ato de fala, e, acima de tudo, aos interlocutores concretos.

Tudo isso lança uma nova luz sobre o problema da consciência e da ideologia. Fora de sua objetivação, de sua realização num material determinado (o gesto, a palavra, o grito), a consciência é uma ficção. [...] enquanto expressão material estruturada (através da palavra, do signo, do desenho, da pintura, do som musical, etc.), a consciência constitui um fato objetivo e uma força social imensa (BAKHTIN; VOLOCHINOV, 2006, p.117-118).

Bakhtin/Volochinov (2006, p. 36) ressalta o excepcional valor de representatividade da palavra no primeiro plano do estudo das ideologias, por seu valor enquanto fenômeno ideológico e pela nitidez facultada por sua estrutura semiótica.

A palavra acompanha e comenta todo ato ideológico. Os processos de compreensão de todos os fenômenos ideológicos (um quadro, uma peça musical, um ritual ou um comportamento humano) não podem operar sem a participação do discurso interior. Todas as manifestações da criação ideológica - todos os signos não-verbais - banham-se no discurso e não podem ser nem totalmente isoladas e nem totalmente separadas dele. (BAKHTIN; VOLOCHINOV, 2006, p. 37-38).

Bakhtin/Volochinov (2006, p. 38) entende que a palavra não pode superar qualquer signo ideológico, uma vez que não há como representar adequadamente, por palavras, uma pintura, uma peça musical, um ritual religioso, um sentimento amoroso, um gesto humano, no entanto, quando se tenta estabelecer os sentidos 
de textos não-verbais, esses são apoiados por palavras. Os signos culturais são dotados de sentido e esse sentido se estabelece como parte da unidade da consciência verbalmente constituida (BAKHTIN; VOLOCHINOV, 2006, p. 38). Nas interações entre sujeitos participantes de grupos organizados, as comunicações estabelecem-se a partir de enunciados concretos, materializados em gêneros discursivos, permeados por signos semióticos dialogicamente compartilhados. Entende-se, por conseguinte, que ensinar língua é ensinar gêneros e sua aplicabilidade nas diversas esferas em que o sujeito atua.

$\mathrm{Na}$ concepção de Bakhtin e do Círculo, a linguagem é dialógica, e os sentidos são produzidos na interação entre subjetividades. A subjetividade é entendida em termos psíquicos, sociais e históricos e considerada a condição de possibilidade da subjetividade, uma vez que o sujeito do discurso é interagente de outros agentes (SOBRAL, 2009, p. 32).

$\mathrm{Na}$ perspectiva bakhtiniana (BAJTIN, 1997; BAKHTIN, 2003), todo ato, toda voz humana envolve outras vozes e essa confluência de vozes, esse dialogismo, de cunho filosófico, discursivo e textual, num primeiro plano, designa a condição de um sujeito existir na relação com outros e de agir sempre frente a esses sujeitos e de seus atos, no confronto de um $e u$ e um $t u$, o que permite que um ser se torne social na interação, numa inter-relação com outros seres; em segundo, no plano do discurso, faz com que o sentido se estabeleça entre formas de enunciados/discursos já produzidos e que podem vir a ser produzidos. Antes de se pronunciar diante do outro, o sujeito responde a esse outro, resposta ativa presumida do outro, considerando-se as formas textuais tipicamente presentes em discursos; em terceiro, o dialogismo é a base de uma forma de composição de enunciados. O dialogismo é o princípio constitutivo da linguagem que faz a mediação da realidade semioticamente. $\mathrm{O}$ mundo é semiotizado pelos discursos, e a relação entre esses discursos compostos por diferentes vozes é o dialogismo. Esse dialogismo está presente na constituição do enunciado escolhido para este trabalho. Neste estudo, os conceitos de Bakhtin e do Círculo são utilizados para a análise da reportagem de Brum (2006).

A reportagem, enquanto um enunciado concreto, constitui-se de discursos e sua leitura profícua depende do entendimento da dimensão verbo-visual do texto, uma vez que é a partir da materialidade linguística e imagética que o sentido se estabelece, implicando nas relações dialógicas que o autor-criador estabelece com seus discursos internos, sua memória discursiva e com os discursos éticos, morais, políticos, históricos etc, integrantes e constituintes do momento vivido. Essa materialidade é constituída de unidades discursivas estabelecendo relações com o enunciado, uma vez que todo enunciado representa a posição ativa do falante, caracterizado por uma escolha semântico-objetal. 
Dessa forma, ensinar língua implica levar o aluno a estabelecer sentidos a partir da materialidade dos discursos, compreender e depreender os sentidos que subjazem das palavras, das imagens que constituem os enunciados. Cabe ao professor levar o aluno a compreender que a escolha dos recursos linguísticos e do gênero discursivo se dá em função da ideia do autor, de sua intencionalidade, com foco no sentido e em sua necessidade comunicativa. Essas escolhas determinam as peculiaridades estilístico-composicionais do enunciado, seu primeiro momento.

O segundo momento é o elemento expressivo que lhe determina a composição e o estilo. Isso marca a relação valorativa do autor com o conteúdo do objeto e sentido do enunciado. A relação valorativa do autor com o objeto de seu discurso determina os recursos lexicais, gramaticais e composicionais utilizados. Desse modo, o estilo individual é determinado pelo aspecto expressivo. A "entonação expressiva" ou valorativa "é um traço constitutivo do enunciado" (BAKHTIN, 2003, p. 290). As palavras, nas situações discursivas, são enunciações valorativas, uma vez que adquirem, em determinadas condições político-sociais, valores específicos. Nessas circunstâncias, pode-se compreender seu significado e, mais, ocupa-se frente a elas uma posição responsiva, pois a entonação expressiva pertence ao enunciado, e não à palavra. A palavra, no enunciado concreto, é carregada de tom emocional ou entonação axiológica, por conseguinte, a escolha de palavras guia seu tom emocional, uma vez que na construção do enunciado sempre há a noção do todo. As palavras não são escolhidas uma a uma, mas completam o todo enunciativo. Nesse fazer, a construção do discurso apresenta-se carregada de conhecimento de mundo, valores, tons valorativos e postura axiológica, que caracterizam a alteridade do sujeito que enuncia. A escolha do gênero discursivo também é determinante, já que é marcado de uma expressividade típica, capaz de dar ao leitor indícios do que se pode esperar do enunciado. Ou seja, o gênero ativa, no leitor, uma atitude responsiva frente ao dizer que se realiza. Por ser o enunciado dialógico, constituído de muitas vozes, todo ato traz um tom avaliativo pelo qual o sujeito se responsabiliza e envolve um conteúdo e um processo que adquire sentido pela entoação avaliativa na relação com a responsividade ativa do interlocutor, coautor do enunciado, da produção de seu sentido. Essa entonação pertence ao enunciado, e não à palavra, uma vez que o sujeito autor/leitor estabelece uma posição responsiva no ato de enunciar: cada unidade discursiva carrega consigo um "tom emocional", "um elemento axiológico" (BAKHTIN, 2003, p. 291).

Por conseguinte, ao ensinar leitura, é preciso levar o aluno a se perceber como leitor, como coautor. Ao ativar sua posição responsiva, o aluno deverá recuperar os seus discursos internos e correlacioná-los aos externos, para poder constituir o sentido do enunciado. É nesse enfrentamento de vozes, de versões de mundo que 
se concebe o discurso como dialógico. Na interação entre atos e sujeitos é que se dá o processo contínuo de criação do sentido. Dessa forma, ensinar língua é ensinar o aluno a lidar dialogicamente com os enunciados internos e externos.

A leitura da reportagem, portanto, implica a recuperação dos discursos, das relações dialógicas travadas pelo cruzamento dessas linguagens com os discursos circulantes nas diversas mídias na época de sua composição e é determinada e determinante das esferas de produção, de circulação e de recepção em que se efetiva (BERTI-SANTOS, 2008).

Ao produzir a reportagem, o autor pressupõe que o leitor reconheça, na situação narrada ou na cena criada, o fato que lhe dá origem, identificando as personagens e a situação proposta com uma ou mais notícias veiculadas pela mídia naquele dia ou naquela semana. Para compreender a reportagem, é preciso compreender a construção e a reconstrução do seu sentido, efetuada por seu autor e pelo leitor; mais especificamente, por meio da construção dessas relações inter e extratextuais, autor e leitor poderão identificar o que ocorre na sociedade vigente, bem como a esfera de produção e circulação desse discurso (BERTI-SANTOS, 2008).

Nesse sentido, para estabelecer relações dialógicas com a reportagem História de um olhar, do livro $A$ vida que ninguém vê (BRUM, 2006), é preciso que o leitor esteja ciente de outros discursos com os quais a reportagem interage, constituindo seu sentido. O leitor deve acionar sua memória discursiva e recuperar as outras reportagens que tratam de pessoas da periferia de Porto Alegre, cuja vida é marcada pelas condições precárias impostas pela exclusão social. Esses discursos, a relação dialógica, a interação estabelecida entre eles, a tensão, a polêmica, a diferença, o eu e o outro é o que permite ao leitor constituir o sentido do enunciado.

A reportagem de Brum, entendida como gênero discursivo e dialógico, recupera um momento sócio-político importante de 2006 nas discussões das condições precárias impostas pela exclusão social. A autora resgata discursos sociais e cria seu enunciado verbo-visual, sua reportagem.

Segundo Puzzo (2011, p. 123), o enunciador tem sempre em mente o horizonte social de seu público no momento de sua enunciação. $O$ enunciado é elaborado em função desse duplo que o constitui na linguagem. Dessa perspectiva, a jornalista considera o leitor presumido e a esfera de circulação de sua reportagem. Em função desse horizonte, concretiza, na materialidade linguística, a sua proposta enunciativa. Por isso, ensinar a ler é dar a possibilidade ao leitor de reconhecer os recursos expressivos e os valores socioideológicos que o constituem.

Para Bakhtin, o texto estético representa a forma de um conteúdo, mas que só pode se concretizar no material que está intimamente ligado a ele. Nesse aspecto, a forma de uma obra artística deve ser considerada tanto como parte da 
arquitetônica, axiologicamente voltada para o conteúdo, como também no todo composicional e material, isto é, a técnica da forma. Bakhtin inverte a concepção formalista, apontando que, nos estudos literários, a forma não deve ser interpretada como forma de um material, e sim, "como forma realizada no material e com a sua ajuda, e, dessa maneira, é determinada não só pelo seu objetivo estético, como também pela natureza do material dado" (BAKHTIN, 1990, p.57). Forma e material estão tão intimamente ligados que não podem ser considerados separadamente $\mathrm{e}$ são fundamentais no processo criativo. Para o pensador russo, todos os elementos do discurso que compõem o conjunto artístico não podem ser separados porque, na realidade, fazem parte de um todo orgânico, uma unidade concreta em que os elementos se interpenetram e se condicionam mutuamente. Nas palavras do autor,

En general todos estos elementos subrayados del discurso y de la totalidad artística, a saber: objeto, imagen, ritmo, entonación, etc., pueden aislar-se sólo en abstracto, siendo en la realidad fusionados en una unidad concreta y totalizadora, se interpenetran y se condicionan mutuamente. (BAJTIN, 1997, p. 100)

Nesse sentido, o autor/criador desenvolve papel fundamental como parte do momento constitutivo da forma, é a atividade, organizada e oriunda do interior, do homem como totalidade, que realiza plenamente a sua tarefa, que não presume nada além de si mesmo para chegar à conclusão, é, ademais, o homem todo dos pés à cabeça: ele precisa de si por inteiro, respirando (o ritmo), movimentando-se, vendo, ouvindo, lembrando, amando e compreendendo. (BAKHTIN, 1990, p.68)

Dessa forma, a obra literária é entendida como um produto de criação ativa do autor, que participa inteiramente do processo de criação e, ao mesmo tempo, mantém a distância de seu objeto, para melhor observá-lo. É como se sua obra representasse um projeto visualizado à distância, refletindo e refratando todo seu ser e sua visão valorativa do mundo. Por isso, para Bakhtin, é impossível separar a forma do conteúdo. Eles estão intimamente ligados pelo projeto de natureza axiológica. É preciso entender a forma composicional e o estilo como parte integrante que constituem sua unidade temática. Pode-se afirmar que a materialidade do texto, as escolhas efetuadas pelo autor para cumprir seu projeto, contribuem para compor a arquitetônica da obra e expressam o homem em sua integridade vital, seu caráter valorativo e axiológico. Como afirma Sobral, "a forma arquitetônica se vincula com o projeto enunciativo do autor, com o tipo de relação com o interlocutor que ele propõe" (2010, p.77). 


\section{Peculiaridades da reportagem de Eliane Brum}

Com base nos pressupostos teóricos apontados, será realizada a análise da reportagem de Brum. Essa reportagem não corresponde ao padrão das reportagens jornalísticas no que tange à forma composicional e ao estilo. A repórter segue um percurso próprio de investigação e vai buscar a informação em locais afastados do olhar da população, escolhendo perfis considerados de pouca relevância, para serem retratados. Ela toma o caminho do jornalismo literário, distanciado do jornalismo objetivo praticado atualmente. Segundo Vilas-Boas (2003 p. 11), o jornalismo literário perdeu espaço no jornal diário, mas ainda é possível praticá-lo, embora a ênfase está nas "pílulas de informação em detrimento dos 'textos para guardar". Brum distancia-se dos textos jornalísticos convencionais pela singularidade do texto escrito e pela articulação com a imagem esteticamente trabalhada, aproximando-se do que Vilas-Boas (2003, p. 10,11) denomina de jornalismo literário.

De acordo com Vilas-Boas (2003, p. 11), a reportagem literária "foge das fórmulas rígidas de estruturação. Suas referências narrativas (procedimentos e técnicas) vêm da literatura. Jornalismo literário não é um jornalismo sobre livros literários. Jornalismo literário é uma filosofia e uma técnica". Mesmo que tenha a função de informar, o jornalista pode recorrer aos recursos expressivos próprios da literatura para aproximar-se de seu objeto e envolver o leitor.

As reportagens de Brum diferenciam-se, ainda, pela sua forma composicional, em que se mesclam as linguagens verbal e visual e se distanciam do padrão da linguagem jornalística mais objetiva e direta. Brum posiciona-se como repórter compromissada com o contexto social, ao colocar em evidência fatos pouco significativos do ponto de vista adotado pela mídia. As personagens reais que entram em sua galeria investigativa são pessoas marginalizadas pela sociedade, sem rosto e sem voz. Brum apresenta um modo de observar o cotidiano, expressando, em um tom valorativo, os problemas sociais político-econômicos. De forma criativa, apresenta uma linguagem quase poética, num estilo marcado pela estruturação sintática, muitas vezes, fragmentada, sem prejuízo da unidade enunciativa.

Cumpre um papel pouco usual de investigação na mídia impressa atual. $\mathrm{O}$ título do livro $A$ vida que ninguém vê (2006), de onde foi selecionado o texto para análise neste artigo, expressa bem a proposta jornalística da autora. Apesar do estilo mais literário, Brum trata de fatos reais, voltados a pessoas da periferia de Porto Alegre, cuja vida é marcada pela precariedade e exclusão social.

A coletânea de reportagens do livro conta também com as imagens fotográficas de vários repórteres, esteticamente trabalhadas de modo a dialogar com o texto escrito, provocando efeitos de sentido mais intensos em suas relações com o relato jornalístico. Mais especificamente, a reportagem objeto de análise conta 
com a produção de André Feltes, disponibilizada pela Agência RBS de Notícias, e foi publicada no Jornal Zero-Hora, em 18 de setembro de 1999.

Com a perspectiva de tocar o leitor, Brum, no papel de repórter, procura mobilizar o leitor, ou melhor, situá-lo, de modo provocativo, em um contexto desconhecido da maioria da população urbana. Em uma linguagem simples, muitas vezes poética, recorrendo a imagens literárias e ao discurso indireto livre, a repórter abandona a premissa jornalística de objetividade. No relato investigativo, sua linguagem mescla-se com a de seus entrevistados, o que permite trazer o leitor para mais próximo dos perfis retratados. É o caso da reportagem História de um olhar.

O texto trata de uma personagem adulta, carente, que chega à escola, pelo lado de fora, aproximando-se da sala de aula da professora Eliane Vanti. O olhar curioso de Israel chama imediatamente a atenção da mestra, empenhada em transmitir seus conhecimentos aos alunos. Tocada pela presença do adulto que insistentemente espia pela janela da sala de aula, Eliane o convida para participar das aulas, junto com os demais alunos. Para relatar esse episódio, Brum apresenta Israel, situando-o no contexto social de origem, a vila Kephas, uma comunidade carente, criada por operários da indústria desempregados. Tal como Israel, os operários eram discriminados por outros moradores. Ele era, nas palavras de Brum, "o enjeitado da vila enjeitada”. Órfão de mãe, vivendo com a madrasta, o pai pedreiro e uma irmã doente, Israel apresentava um desvio de comportamento, era considerado pela comunidade um "desregulado das ideias". Por essa deficiência, era apedrejado e maltratado pelos garotos da vila. Nessas circunstâncias, a professora se depara com Israel. Assim a repórter descreve a cena:

Eliane viu Israel. E Israel se viu refletido no olhar de Eliane. E o que se passou naquele olhar é um milagre de gente. Israel descobriu um outro Israel navegando nas pupilas da professora. Terno, especial, até meio garboso. Israel descobriu nos olhos da professora que era um homem, não um escombro. (BRUM, 2006, p. 23).

O relato segue acompanhando o desenrolar da cena, passo a passo, de modo a criar um ambiente de intimidade do leitor com a história real da personagem reportada. Israel, pouco afeito à receptividade de seus semelhantes, vai, aos poucos, chegando mais perto da sala de aula. Primeiro consegue entrar na escola e depois na sala de aula. Um fato corriqueiro é flagrado por Brum de modo expressivo:

Capturado por essa irresistível imagem de si mesmo, Israel perseguiu o olho de espelho da professora. A cada dia dava um passo para dentro do olhar. E, quando perceberam, Israel estava no interior da escola. E, quando viram, Israel estava na 
Linha D'Água (Online), São Paulo, v. 28, n. 2, p. 26-43, dez 2015

janela da sala de aula da $2^{\mathrm{a}}$ série C. Com meio corpo para dentro do olhar da professora. (BRUM, 2006, p. 23, grifos nossos).

A integração de Israel na comunidade escolar se faz aos poucos num movimento de compartilhamento que Brum acompanha paulatinamente: "A imagem se multiplicou por 31 pares de olhos de crianças. Israel, o pária, tinha se transformado em Israel, o amigo." (BRUM, 2006, p.24). Por meio de recursos estilísticos como metáforas, metonímias, sinestesias, Brum imprime seu tom valorativo, sua postura axiológica frente à realidade, poeticamente apresentada, sem perder a dureza do fato nem a beleza do ato. Observa-se que a expressividade da linguagem empregada na reportagem deixa entrever a cumplicidade da repórter com a cena relatada. Entretanto, é preciso ressaltar que o estilo de Brum tem por objetivo envolver o leitor. Essa relação responsiva com o leitor presumido não é aleatória, decorrente apenas de uma estética vazia, da linguagem expressiva por ela mesma. A forma estruturada do relato evidencia o esforço de articulação, para tornar a história envolvente. A repórter procura demonstrar que o acolhimento e o afeto podem resgatar o amor próprio e a dignidade do ser humano. Assim finaliza seu texto: "Israel, depois que se descobriu no olhar da professora, ganhou o respeito da vila, a admiração do pai. Vai ganhar uma vaga oficial na escola. Já consegue escrever o 'P' de professora. E ninguém mais lhe atira pedras" (BRUM, 2006, p. 25).

É preciso ressaltar que Brum não perde o foco de sua reportagem e destaca também a transformação da professora nesse processo. $\mathrm{Na}$ verdade, a atuação interativa mobiliza a vida dos dois lados. A insatisfação, a amargura, que, muitas vezes toma, de assalto, a atividade da profissional, decorre muitas vezes da falta de perspectiva. Quando a situação se reverte, a personagem encontra motivação para prosseguir. É o que a repórter deixa entrever ao final do texto: "A professora, depois que se descobriu no olhar de Israel, ri sozinha e chora à toa. Parou de reclamar da vida e as aulas viraram uma cantoria. A redenção de Israel foi a revolução da professora" (BRUM, 2006, p.25).

Ao final do texto, a repórter destaca a acolhida de Israel pela comunidade da vila Kephas, cujo significado na origem grega do termo é pedra, sólida, dura, mas também basilar. A repórter define o termo como forma de enfatizar a transformação verificada no comportamento geral dos habitantes de Kephas, ressaltando o tom valorativo da unidade discursiva empregada no enunciado: ao desfilar, Israel é aplaudido de pé pela "Vila Pedra". A vila transformou-se, a pedra foi moldada. 
Linha D'Água (Online), São Paulo, v. 28, n. 2, p. 26-43, dez 2015

\section{Peculiaridades da linguagem escrita}

A reportagem sintetiza, de maneira incisiva, um instante significativo da vida de Israel e de Eliane Vanti. Ambos passaram por um processo de transformação existencial relatado pela repórter. $\mathrm{O}$ enunciado deixa entrever o posicionamento axiológico de Brum pela expressividade linguística. Os parágrafos são constituídos por períodos breves, sem conectivos, criando certo impacto pela forma pontual com que flagra alguns detalhes. O parágrafo inicial marca o estilo inusitado adotado pela autora: "O mundo é salvo todos os dias por pequenos gestos. Diminutos, invisíveis. O mundo é salvo pelo avesso da importância. Pelo anônimo da evidência. O mundo é salvo por um olhar. Que envolve e afaga. Abarca. Resgata. Reconhece. Salva”. (BRUM, 2006, p. 22).

O trecho de abertura contraria o lead instituído como regra pela norma jornalística, não só pela ausência das informações fundamentais - Quem? Quando? Onde? Como? Por quê? -, mas também pela estruturação sintática do parágrafo inicial, composto por períodos simples, encadeados por frases nominais: "Diminutos, invisíveis"; "Pelo anônimo da evidência". Utiliza a voz passiva: "O mundo é salvo pelo avesso da importância", e transgride as regras gramaticais com fragmentos de frases compostos apenas por agente da passiva: "Pelo anônimo da evidência"; por orações subordinadas adjetivas: "Que envolve e afaga". Utiliza uma gradação positiva crescente, constituída apenas por verbos: "Abarca. Resgata. Reconhece. Salva”, intensificando as ações e evidenciando o acolhimento.

Além dessa peculiaridade transgressora, há o emprego de adjetivação valorativa, presente desde o início: "pequenos", "diminutos". Dessa forma, é possível identificar o tom adotado na reportagem desde seu início até o parágrafo final, sintetizado em duas linhas: "Em 7 de Setembro, Israel desfilou. Pintado de verde-amarelo, aplaudido de pé pela Vila Pedra". (BRUM, 2006, p.25).

Além da estruturação sintática, a autora recorre a figuras de linguagem, entre elas, de modo mais significativo, a metonímia, imagem articuladora da unidade textual, presente no título e na ação interativa Israel/professora, responsável pela transformação ocorrida na vida de ambos, de acordo com a perspectiva de Brum: "Israel estava todo dentro do olhar da professora"; "Israel, capturado pelo olhar da professora, nunca mais o abandonou"; "E foi assim que o olhar escorreu pela escola e amoleceu as ruas de pedra” (BRUM, 2006, p.24).

\section{Relações dialógicas: imagem, texto, contexto}

O título do livro $A$ vida que ninguém vê é sugestivo e dialoga com todas as reportagens que nele se encontram. As fotos que ilustram cada uma das reportagens 
apresentam a mesma característica: flagradas em preto e branco, com um cenário não muito nítido, as personagens apresentam-se pouco delineadas contra o fundo escuro e os traços de seus semblantes pouco destacados, como se eles não fossem relevantes. Entretanto, todas as fotos apresentam um enquadramento específico, colocando em relevo a parte mais importante daquele perfil, cujo destaque é dado pelo texto verbal.

A fotografia que ilustra a reportagem selecionada está posicionada mais à direita no conjunto de duas páginas, ocupando três quartos do espaço disponível. No lado esquerdo, o espaço restante é ocupado pelo título centralizado, grafado em branco sobre fundo preto. O cenário é o da sala de aula:

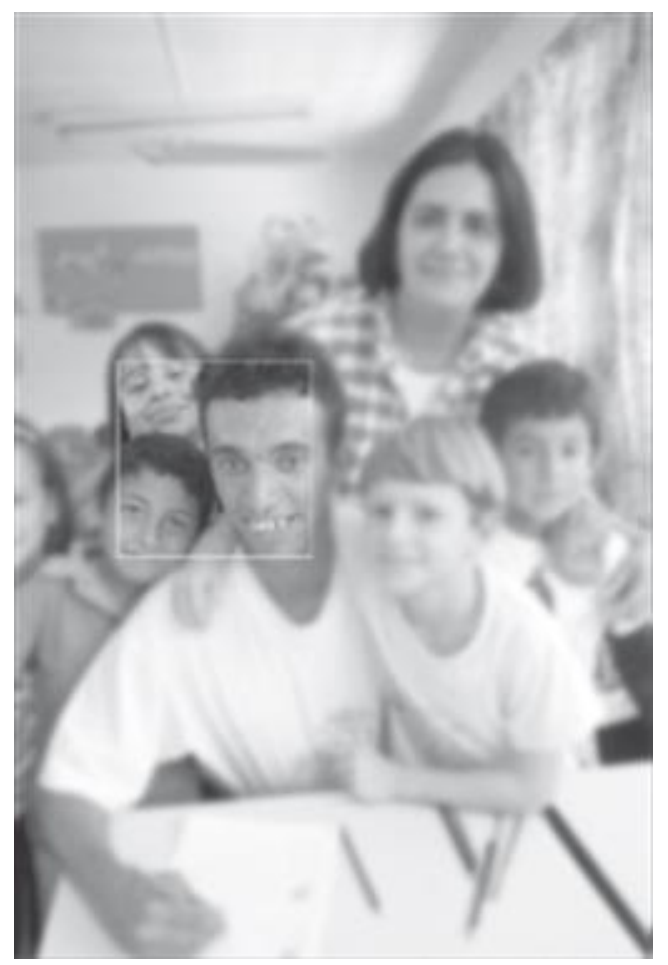

Fonte: Brum (2006, p.20-21).

A professora, em pé, está cercada pelas crianças que se aglomeram em torno de Israel. $\mathrm{O}$ fundo acinzentado do cenário contrasta com o fundo escuro da primeira parte da página. Israel encontra-se sentado em uma das carteiras escolares sobre a qual é possível visualizar uma folha de papel e alguns lápis. A foto apresenta, em destaque pelo enquadramento, os semblantes de Israel e de duas crianças que dele se aproximam. A cena parece registrar o momento de integração de Israel ao grupo de alunos congregados por Vanti. No cenário desfocado, sobressaem-se a face e os olhos sorridentes de Israel. $\mathrm{O}$ enquadramento imagético dialoga com a figurativização metonímica do texto verbal. 
De certo modo, a imagem antecipa o teor da reportagem, dialogando com o tema do enunciado. Antecipa o acolhimento final e o compartilhamento de Israel com os alunos em sala de aula. $\mathrm{O}$ agrupamento ao seu redor desvela seu acolhimento, refletido no ar de satisfação de sua expressão facial.

$\mathrm{Na}$ captação e reprodução da imagem, o fotógrafo interpreta o tema da reportagem: a inclusão social pelo afeto. $\mathrm{O}$ lirismo que percorre o texto verbal também é visível no tratamento fotográfico. A cena retratada em cores esmaecidas e o enquadramento expressivo do semblante de Israel e das duas crianças demonstram um trabalho estético que procura alcançar a mesma expressividade do enunciado verbal, formando, com ele, uma unidade temática. A ênfase do cenário - em preto, branco e cinza - procura destacar o tom lírico adotado na reportagem e em todo o livro. As cores desempenham papel fundamental na constituição de sentido, conforme elucida Guimarães (2003). Contrariamente à teoria que atribui um sentido simbólico às cores independentemente do contexto em que se encontram, Guimarães (2003) procura demonstrar que o valor de signo representado nas cores só pode ser avaliado em relação aos enunciados aos quais se integram. No caso da reportagem, a ausência de cores vibrantes, como as que ilustram as reportagens dos diários impressos, sinaliza o contraponto com o sensacionalismo noticioso. Evidenciam a temática da tratativa de cidadãos pouco valorizados, reconhecidos, percebidos pela sociedade. A cor cinza passa desapercebida pelo olhar, é o tom em que a vista descansa das outras cores. Corrobora com a característica do estilo de Brum em consonância com sua proposta comunicativa. É importante demonstrar, no ato de leitura, que todos os elementos da forma composicional do enunciado produzem efeitos de sentido, cabendo ao professor a mediação desse fazer. Como propõe Dondis (2003), é preciso desenvolver o alfabetismo visual, não de modo aleatório, mas na observação concreta de seus elementos quando integrados a um contexto enunciativo. A essa articulação a autora denomina de sintaxe visual. Nessa direção, a apresentação de Israel, em primeiro plano, cria efeitos de sentido pela valorização de sua expressão facial, pelo brilho dos olhos e pelo enquadramento que o destacam do conjunto dos alunos que o rodeiam.

A leitura da foto que abre a reportagem, na relação com o texto verbal, é necessária para estabelecer sentido no enunciado, como um todo: a imagem centrada em Israel e o cenário da sala de aula, com as crianças que o rodeiam e a professora, antecipam a integração de Israel à comunidade escolar.

Ao proceder à leitura, todos esses elementos devem ser igualmente considerados. O leitor deve acionar sua memória discursiva, estabelecer dialogicamente os sentidos que subjazem aos enunciados verbo-visuais. Igualmente deve interpretar que as cores que preenchem a imagem sinalizam o tom da reportagem 
expresso de modo responsivo pelo fotógrafo. Como sugere Brait (2013), as linguagens verbal e visual devem ser consideradas numa unidade integradora dos enunciados, convergindo para o tema. A figurativização imagética, representada na foto pela centralização no olhar de Israel, antecipa, de certo modo, a leitura da reportagem.

Dessa forma, ao exercitar a leitura integrada das imagens em relação ao texto, procura-se evidenciar as peculiaridades verbo-visuais que o constituem de modo a resgatar a arquitetônica de sua composição. Como afirma Brait,

é necessário considerar suas dimensões (interna/externa), de maneira a explicitar as inter-relações dialógicas e valorativas (entoativas, axiológicas) que o caracterizam enquanto possibilidade de compreender a vida, a sociedade, e a elas responder. Esse movimento amplo, e não apenas descritor das estruturas, da forma composicional, visa justamente à forma arquitetônica do gênero, do texto, dos textos. (BRAIT; PISTORI, 2012, p.378).

Os valores axiológicos que se manifestam no texto podem ser percebidos de modo mais consistente, o que torna a leitura produtiva. Desse modo, a linguagem é tratada em sua realidade viva, como propõe Bakhtin (2003), e não como modelo a ser imitado. A forma de ler procura estabelecer as relações dialógicas suscitadas pela reportagem, entendida como enunciado concreto.

Conforme Brait e Pistori (2012), para tratar dos gêneros discursivos em sala de aula, não basta observar suas características genéricas, é necessário situá-los em seu contexto sócio-histórico, apontando as peculiaridades constitutivas que os distinguem de outros enunciados. No caso específico de reportagens jornalísticas, as peculiaridades se concretizam na proposta autoral e no estilo do texto, como marca de sua autenticidade.

A proposta de leitura dessa reportagem procura ativar respostas produtivas, sinalizando para os alunos os efeitos de sentido sugeridos pela composição verbo-visual do texto. Procura também conduzir o leitor ao contexto social de produção, ao lugar de onde enuncia a repórter. Os conflitos e as tensões relatados no texto podem ser observados de modo mais eficaz quando destacados na materialidade verbo-visual, de modo a ativar a memória discursiva do leitor e levá-lo à conclusibilidade enunciativa como propõe Bakhtin (2003). Segundo o autor, os enunciados terminam, de modo relativo, no ponto final. Isso porque só as respostas de seus leitores darão a conclusibilidade efetiva esperada pelo enunciador. 
Linha D'Água (Online), São Paulo, v. 28, n. 2, p. 26-43, dez 2015

\section{Conclusão}

A análise dessa reportagem jornalística teve por objetivo demonstrar como a linguagem verbo-visual do texto desempenha um papel importante na constituição de sentido de reportagens midiáticas. No percurso interpretativo da verbo-visualidade, a leitura torna-se mais eficaz, podendo suscitar atitudes responsivas mais ativas pelos desdobramentos possíveis de interpretação.

Levar o leitor a entender essas atitudes responsivas, o dialogismo, as relações dialógicas, é levá-lo a uma leitura crítica de um enunciado. Ao considerar a linguagem verbo-visual integrada ao todo enunciativo, evitou-se a análise seccionada de um ou de outro âmbito do texto. A linguagem visual geralmente é deixada em segundo plano ou, então, analisada de modo estanque, sem que se observe sua integração ao enunciado, compondo com ele uma unidade temática. Além disso, a teoria dialógica bakhtiniana contribuiu para o aprimoramento da análise do gênero discursivo na percepção do tom avaliativo e das relações dialógicas que o enunciado mantém com o contexto sócio-histórico, evitando-se, assim, separar forma e conteúdo, um dos principais problemas que afeta os estudos da linguagem.

A palavra no enunciado concreto é carregada de tom emocional ou entonação axiológica. Por conseguinte, quando o autor-criador seleciona as palavras para o enunciado, elas ganham o estatuto de unidades discursivas, e o enunciado passa a ser guiado pelo tom emocional, uma vez que, na construção dele, evidenciam-se as marcas ideológicas, a alteridade do enunciador.

No imbricar de discursos, nas relações dialógicas, o sentido do enunciado se estabelece. $\mathrm{O}$ autor, ao construir seu discurso, responde ao leitor presumido e o leitor reconstrói o enunciado a partir de sua memória discursiva, das relações dialógicas que consegue travar com os discursos imbricados na reportagem e com os discursos sociais, ideológicos no tempo e espaço em que se encontra. Esse é o papel que a escola deve desempenhar na formação de leitores profícuos.

A leitura crítica de um enunciado, na perspectiva dialógica de Bakhtin e do Círculo, considera a materialidade e o contexto do discurso para estabelecer seu sentido. $\mathrm{O}$ contexto não é apenas o imediato, mas o sócio-histórico-ideológico em que autor, herói e leitor se inserem. Assim, para uma leitura crítica de uma reportagem, nessa perspectiva, é necessário que autor e leitor estabeleçam relações dialógicas, imbriquem discursos, compartilhem saberes e estabeleçam atitudes responsivas frente ao outro e ao enunciado, considerando a materialidade e a arquitetônica que emprestam ao discurso o tom valorativo pelas unidades discursivas resultantes da escolha enunciativa do autor.

Dessa forma, para a compreensão do verbo-visual, é necessário entender a ideologia que subjaz ao signo e permeia as relações dialógicas entre sujeitos. 
Linha D'Água (Online), São Paulo, v. 28, n. 2, p. 26-43, dez 2015

Ideologia que só pode ser explicada a partir do material social particular de signos criados pelo homem, produto da consciência individual como fato socioideológico e que se realiza na interação semiótica de um grupo social organizado.

\section{Referências}

BAJTIN, Mijail Mijailovich. Hacia una filosofia del acto ético. De los borradores: y otros escritos. Trad. del ruso Tatiana Bubnova Rubí. Barcelona: Anthropos; San Juan: Universidad de Puerto Rico, 1997.

BAKHTIN, Mikhail Mikhailovich. Questões de literatura e estética: a teoria do romance. Trad. Aurora F. Bernardini et al. 2.ed., São Paulo: Hucitec, 1990.

. O gênero do discurso. In: . Estética da criação verbal. Trad. Paulo Bezerra, 4.ed. São Paulo: Martins Fontes, 2003, p. 261-306.

(VOLOCHINOV). Marxismo e flosofia da linguagem. Trad. Michel Lahud e Yara Frateschi Vieira. 12.ed., São Paulo: Hucitec, 2006.

BERTI-SANTOS, Sonia Sueli. Análise do verbo-visual de textos em hipermídia: a charge. In: ENIL - Encontro Nacional de Interação em Linguagem Verbal e Não-Verbal; SIACD - Simpósio Internacional de Análise Crítica do Discurso, 8, 2008, São Paulo. Anais... São Paulo: FFLCH/USP, 2008. Disponível em: <http://www.fflch.usp.br/dlcv/enil/ pdf/19_Sonia_Sueli_BS.pdf>.

. A análise dialógica do discurso: a materialidade linguística e a constituição de sentido. IN: CABRAL, Ana Lúcia. Tinoco; BERTI-SANTOS, Sonia Sueli (orgs.). Discursos em diálogo: leitura, escrita e gramática. São Paulo: Terracota, 2011, p. 99-118.

BRAIT, Beth. Olhar e ver: verbo-visualidade em perspectiva dialógica. Bakbtiniana: Revista de estudos do discurso, São Paulo, v.8, n.2, p. 43-66, jul/dez, 2013. Disponível em: <http:// revistas.pucsp.br/index.php/bakhtiniana/article/view/16568/12909>. DOI: 10.1590/ S2176-45732013000200001.

; PISTORI, Maria Helena. A produtividade do conceito de gênero em Bakhtin e no Círculo. Alfa, São Paulo, v.56, n.2, p.371-401, 2012. Disponível em: <http://seer.fclar.unesp.br/ alfa/article/view/5531/4343>. DOI: 10.1590/S1981-57942012000200002. 
Linha D'Água (Online), São Paulo, v. 28, n. 2, p. 26-43, dez 2015

; LOPES-DUGNANI, Bruna. Em cartaz, a cara e o corpo da linguagem das ruas! In: BRAIT, Beth; MAGALHÃES, Anderson Salvaterra (orgs.). Dialogismo: teoria e(m) prática. São Paulo: Terracota, 2014, p.116-132.

BRUM, Eliane. História de um olhar. In: $A$ vida que ninguém vê. Porto Alegre: Arquipélago, 2006, p.20-25.

COSTA, Cristiane. Pena de Aluguel: escritores e jornalistas no Brasil 1904 \& 2004. São Paulo: Cia das Letras, 2005.

DONDIS, Donis. Sintaxe da linguagem visual. Trad. Jefferson L. Camargo. São Paulo: Martins Fontes, 2003.

FARINA, Modesto. Psicodinâmica das cores em comunicação. 4.ed. São Paulo: Edgard Blücher, 1986.

GUIMARÃES, Luciano. As cores na mídia: a organização da cor-informação no jornalismo. São Paulo: Annablume, 2003.

PUZZO, Miriam Bauab. A pontuação na constituição de sentido: uma perspectiva discursiva. In: CABRAL, Ana Lúcia Tinoco; BERTI-SANTOS, S. S. (orgs.) Discursos em diálogo: leitura, escrita e gramática. São Paulo: Terracota, 2011, p.119-135.

SOBRAL, Adail. Do dialogismo ao gênero: as bases do pensamento do Círculo de Bakhtin. Campinas: Mercado das Letras, 2009.

A estética em Bakhtin: literatura, poética e estética. In: PAULA, Luciane de; STAFUZZA, Grenissa (orgs.). Círculo de Bakbtin: teoria inclassificável. Campinas, S.P: Mercado de Letras, 2010, p.53-88.

VILAS-BOAS, Sérgio. O estilo magazine: texto em revista. São Paulo: 1996.

. Perfis e como escrevê-los. São Paulo: Summus, 2003.

VOLOCHÍNOV, Valentin Nikolaevich. A construção da enunciação e outros ensaios. Trad. João Wanderley Geraldi. São Carlos: Pedro \& João, 2013.

Recebido: 23/10/2015.

Aprovado: 26/10/2015. 